\title{
The Precession of Simulacra of the Great Terror and Dissolution of the Communist Party of Poland (1936-1938)
}

\author{
Ihor V. Rymar \\ M. P. Dragomanov National Pedagogical University, Kyiv
}

\begin{abstract}
The purpose of this article is to analyze quite a complex and versatile phenomenon of the Great Terror of 1936-1938 and the dissolution of the Communist Party of Poland (CPP) through the prism of the French philosopher Jean Baudrillard's postmodernist concept of a simulacrum. Using some of Baudrillard's basic concepts of simulacrum and dissuasion and also on the basis of published archival documents and monographic studies related to this period, we investigate one of the major tools of terror - 'the purge' and also study the process of deployment of the Great Terror, the involvement of the Third International and foreign Communists in Moscow in the process of repression and the 'purge'. We also make an attempt to find out within the postmodernist framework the reasons for the elimination of the CPP ruling elite that stayed in Moscow and for the complete dissolution of the party which was a part of the Third International from the moment of its uprising. The obtained results allow expanding the existing field of interpretations and explanations of the causes and motives of the Great Terror, and the place the Third International and the CPP used to occupy in this process.
\end{abstract}

Why such a great fuss over the trial. Incomprehensible. An atmosphere has been created of extreme unrest among the population, mutual suspicion, denunciations, and so forth. Trotskyism has been killed - why such a campaign?

Diary of $G$. Dimitrov February 2, 1937

Social Evolution \& History, Vol. 18 No. 1, March 2019 47-66

(C) 2019 'Uchitel' Publishing House

DOI: $10.30884 / \mathrm{seh} / 2019.01 .03$ 
The epigraph conveys the impression produced by the trial of the Trotskyist-Zinoviev group on Georgi Dimitrov, the General Secretary of the Third International (Comintern), and his friends, Leon Feuchtwanger and Maria Osten, who lived in Moscow from the end of 1936. The record of December 18, 1936, when Feuchtwanger and Osten visited the court, attests the lack of understanding of the reasons for the trial and subsequent capital sentences, as well as the lack of evidence, except for the accusations; so there is a remark that 'since the Soviet regime is so powerful that it has nothing to fear from people sitting in prisons' (Dimitrov 2003: 44).

Approximately the same impression arises among the historians when they take up the study of the Great Terror of 1936-1938. The absurdity, mass fear and distrust, when anyone could be accused or even worse, be 'appointed' 'the nation's enemy'; the struggle of all against all, when only those who occupied the highest positions in the power hierarchy and those who performed the role of obedient tools in the hands of the former remained relatively safe; absolute vulnerability, total precession of simulacra, when the idea of an imaginary enemy precedes and stimulates the search of a real enemy, which actually hardly exists.

The precession itself, prepositions of similar objects, simulating, transmitting, depicting or representing reality, and dissuasion laid the foundation for the 1936-1938 repressions. It is the same precession and dissuasion that we find when studying the documents related to the repression of the Comintern representatives and dissolution of the Communist Party of Poland (CPP), the massacres of the old party members of the fraternal Communist Party, who had never been in opposition to the then-existing regime or who knew too much and could be unreliable.

The systematic analysis of data associated with the 1936-1938 Great Terror is still relevant, despite the powerful array of the processed material, and leaves a field for new approaches and interpretations. Taking this into consideration, the relevance of this article is to investigate the Great Terror of 1936-1938 and the dissolution of the Polish Communist Party as an element of the purges in the Third International and repressions against foreigners (Poles, Latvians, Estonians, Germans, etc.) as a part of the great precession of simulacra during the period from 1936 to 1938 . The precession of simulacra, as something that cannot arise and exist in isolation from reality in its entirety and complexity, demands a systematic and multifactorial 
analysis of the causes and motives of the Great Terror of 1936-1938 and the elimination of the CPP in 1937.

The Great Terror, as a global phenomenon, involved the whole population of the USSR, all societal layers including foreigners and political migrants, and all its structures and levels. The study of the Great Terror, the discovery of its causes and effects on social structures and the party involved many well-known scholars, both Western and Russian. Summing up their achievements, the Russian researcher, professor Andrey Medushevsky distinguishes seven main aspects (psychological, institutional, functional and sociological approaches, factor of personality, multivariate analysis and refusal of rational explanation of this phenomenon), which shed light on the Great Terror, study the causes of this phenomenon and try to answer the question why this happened (Medushevsky 2010). Besides, 'when studying the mechanisms of the 1936-1938 repression certain contradictions have been revealed' (Ibid.). First of all, they relate to the questions of how and where the very idea of the Great Terror came from, its institutional basis, whether it developed spontaneously or under Joseph Stalin's control, and finally, where is the boundary between terror and other forms of violence, inherent to Stalin's management system. The most complex issue of repressions can be studied through the application of a multifactorial analysis. The great terror, as the Stalinist system in general, cannot be explained by any single reason. In fact, both internal and external factors influenced Stalin's policy and governance. Focusing on social, political or personal aspects, most of the theories, in our opinion, ignore that repressions were a total precession of simulacrum and dissuasion. It is worth paying attention to the fact that the Russian analogue of the concept of 'dissuasion' - apotrophy - although it is very close but still this term of Greek origin does not fully reflect the essence of the concept of 'dissuasion'. Therefore, we are inclined to use the original notion used by the French philosopher Jean Baudrillard 'dissuasion', which simultaneously combines the meanings of 'loss of beliefs, disbelief, rejection' with 'intimidation, frightening', as well as 'deterrence, retention, and prevention' (Baudrillard 2015: 215).

The historiography on the Great Terror, repressions over the Poles in the USSR and the dissolution of the CPP, as one of the constituent elements of the problem, is huge. Many Western (Robert Conquest, Nicolas Werth, William J. Chase, Norman Naimark, Terry Martin, Brigitte Studer, Berthold Unfried, etc.) as well as Russian (V. Khaustov, A. Vatlin, F. Firsov, M. Panteleyev, L. Babichenko, etc.) histo- 
rians addressed this issue; however, their approaches and interpretations remain in the discussion field.

The core of the problem is presented in the collection of documents (Adibekov, Anderson and Shirinya 2004; Davies, Khlevniuk and Rees 2001; Yakovlev 2004) which cover the relations within the ruling elite of the VKP(b) (between Joseph Stalin and his immediate circle) and between 'the master of the Kremlin' and state structures, including III International and his general secretary Georgi Dimitrov, who were also involved into the explosion of the Great Terror of 1936-1938 and documents from the funds of the Russian State Archive of Social and Political History (RGASPI) on the dissolution of the CPP (RGASPI 505/1/74, RGASPI 546/1/418). An important source is Dimitrov's Diary in which we find the information about the terror itself, the role of Stalin in repressions, and recollections of Margarete Buber-Neumann (the wife of Heinz Neumann, one of the Comintern functionaries) who witnessed the 1936-1938 repressions and was repressed herself. A certain difficulty with respect to the sources related to the Great Terror and the 1930s in general is the fact that Stalin's instructions hardly had a clearly expressed character and orientation, which affected the language of the documents which he personally approved and reviewed acting as the final authority.

In the period from September 1936 to November 1938, when Nikolai Yezhov headed the People's Commissariat for Internal Affairs (NKVD) bodies with which the Great Terror was associated, there were unprecedented repressions that touched a large part of population: from ordinary Soviet citizens to the leaders of the Political Bureau. The Great Terror included more than a dozen operations, planned at the highest level of Stalin and Yezhov. According to the French historian Nicolas Werth, these operations were carried out against the 'enemies' who were divided into two 'lines': the 'kulak line' (defined by operational order No. 00447 of July 30, 1937) and the 'national line' (including all foreign citizens coming from the countries that were considered hostile to the USSR and Soviet citizens having any connection with them) (Werth 2010: 237). The main events to which the attention of Western observers was drawn were three indicative Moscow processes - the 'case of 16' (1936), 'the case of 17' (1937), and 'the case of the 21' (1938). During these processes, the most prominent followers of Vladimir Lenin (Zinoviev, Kamenev, Krestinsky, Rykov, Pyatakov, Radek, Bukharin, etc.) confessed in their crimes: the organization of terrorist centers aimed at the overthrow of Soviet power, the murder of its leaders, the restoration of 
capitalism, the commission of acts of harm, the destruction of the Soviet military power, the split of the USSR between foreign states and separation of Russia, Ukraine, Belarus, Georgia, Armenia, and the Soviet Far East. This scene is a remarkable precession of the enemy and an 'operation for the dissuasion of any real process with its operational copy, an ideally descriptive, metastable, programmable mechanism that provides all the signs of the real, bypassing any peripetium' (Baudrillard 2015: 7) was necessary in order to hide the other side the mass repressions of people of any social category. The remarkable illustration is the recording of Stalin's words in Dimitrov's diary entry on November 7, 1937

Therefore, whoever attempts to destroy that unity of the socialist state, whoever seeks the separation of any of its parts or nationalities - that man is an enemy, a sworn enemy of the state and of the peoples of the USSR. And we will destroy each and every such enemy, even if he was an old Bolshevik; we will destroy all his kin, his family. We will mercilessly destroy anyone who, by his deeds or his thoughts - yes, his thoughts - threatens the unity of the socialist state (Dimitrov 2003: 65).

Subsequently, during the Great Terror, precession and dissuasion expanded to the borders of the entire Soviet Union. Inconspicuous for the foreign observers, this process would affect the consciousness of the Soviet citizens of all sections of society, squeezing the partystate to the size of the state party. The years 1936-1938 appeared the last act in the political struggle that eliminated Stalin's main rivals.

One of the main tools that supported the repressions carried out by the NKVD was the 'purge'. The purge and show trials along with other components of the Totalitarian Triade of Control (the phenomena of criticism/self-critique, biography and autobiography) were the elements of terror and in a certain sense its information basis. 'The purge is the manifestation of the party's self-criticism and its highest form' (Kaganovich 1933). In contrast to Kaganovich (the People's Commissar of Communications during the studied period), Margarete Buber-Neumann in her memoirs suggests defining purges as close as possible to the understanding of the party's ordinary member:

This was supposed to be a protective mechanism against 'fraudsters, bureaucrats, dishonest and unstable Communists and Mensheviks...' Purges <...> became a method that kept all party members in fear. In 1936, the cleansing 
carried out, to a certain extent, preliminary work for the NKVD: the desired accusative material against the arrested was gathered earlier in the process of purge (BuberNeumann 1995: 231-232).

Today the term 'purge' is most often used to refer to the Great Terror of 1936-1938. The concept of 'Great Terror' was introduced to the academic community by Robert Conquest, and since then it has been widely used in the world historiography. It is important to understand that the second half of the 1930s witnessed not only purges. Purges became only a part of the 'apocalyptic theater of horror,' according to a well-meaning statement by N. Naimark (Naimark 2011: $85)$, which embraced the USSR in the second half of the 1930s.

The German historians Studer and Unfried directly associate the origins of the 'great purge' of 1936-1938 with the murder of Sergey Kirov in 1934. While prior to that moment a 'purge' meant a periodic 'self-purification' of the party from all kinds of 'unworthy elements' during the campaign of verification (following the definitions by Kaganovich and Buber-Neumann), then in 1936 it acquired a new character. It is significant that the reasons for the exclusion became more and more 'political' - the connection with 'hostile elements', 'Trotskyism', 'victimization', and of course, 'espionage' (Studer and Unfried 2011: 78-79).

The decision of the $7^{\text {th }}$ Congress of the Comintern in 1935 to establish a united anti-fascist front was an implicit confirmation that the bet on the communist parties alone was not justified. The Secretary, member of the Presidium of the Executive Committee of the Communist International (ECCI) and the chief of the Foreign Department of the Cheka and the OGPU (since 1935) Mikhail Moskvin (Meier Trilisser) admitted that neither numerous machines of communist parties nor funding through the ECCI major measures hardly brought the desired results: the mass communist parties were still absent in many European countries while the existing ones, as Moskvin characterized them, had 'a big head on thin, like matches, legs' (Khaustov and Samuelson 2010: 185).

At the same time, up to the mid-1930s there was a significant stiffening of the regime of residence in the territory of the USSR for the representatives of fraternal Communist Parties. Many of the communists who worked in the Comintern were at that time considered as a recruiting base for foreign intelligence. During the first half of the 1930 s, conditions were created in order to quickly expand mass operations in the communist circles in the event of a change in the course of 
punitive politics (Khaustov and Samuelson 2010: 56). Finally, the place and participation of the Comintern was resolved shortly before the start of the Great Terror, at the December plenary session of the Central Committee of the VKP(b) in 1935. The party successfully infiltrated 'open enemies, including even spies of foreign intelligence'. 'They penetrated under the guise of political immigrants and members of the fraternal communist parties.' In this direction, a number of resolutions were directed to strengthen the control of members of the foreign party, designed to expose enemies (Vatlin 1998: 66-69). With this decision, the Comintern was drawn into a circle of continuous inspections that were approaching the culmination of the Great Terror.

In January 1936 a commission was formed, headed by Moskvin. It started to examine all personal cases of employees of the Comintern. In addition, an attempt was made to cover the political migrants who did not work in the Comintern, including those who lived in the periphery (Babičenko 1994/1995: 35-39). The result of implementation of Moskvin's policy was the 'elimination of the staff', as it characterized by Yezhov's opponents in the staff department after his and his 'team' elimination (in November 1938) (RGASPI 546/1/418).

In the purges of the new type, the accusation and results were recorded right from the start. As Unfried noted, the set goals and activities of numerous commissions created between 1936 and 1937 for the purge of the Comintern and emigrant environment were quite clear: to change the Comintern staff and destroy the former frames (Studer and Unfried 2011). One of the Comintern secretaries, Dmitry Manuilsky defined one of the objectives of creating defense system as 'to lead to self-agent class enemy' (Babičenko 1994/1995: 36). The decisive difference between purges and terror of 1936-1938 was that the logic of the latter remained hidden from potential victims, especially from foreigners. The goal was to eliminate the emigrant environment, and the purge then meant a maximum expulsion of foreigners, which also began to count the frames of the fraternal Communist parties. However, it could not be declared openly and without approval of the official ideology. Such actions, as indicated by Unfried, were coded in stereotype representations, mainly in the form of enemy associated with foreign country (Studer and Unfried 2011: 81). In the time of the terror of 1936-1938, foreigners were a desirable target. Being 'foreigners', people fall into the cauldron of repression and terror in which they were pointed as a political factor and were useful as human material to destroy the system (Ochotin and Roginski 2000/2001). 
The 1937 became extremely difficult for the Comintern. All services rushed from the Secretaries to the Communist Party offices. The Commission of the Secretariat of the ECCI consisting of Moskvin, Florin and Anvelt (January 1 - September 17, 1937) and the special Control Commission consisting of Dimitrov, Moskvin, and Manuilsky (established in May 1937) decided to exclude 256 members (Courtois et al. 2001: 284). During the first half of 1937, one-sixth of the staff of the Comintern was dismissed (102 out of 606 employees) with the following wording: 'Caught as an enemy of the party and people', 'the nation's enemy' etc. (Adibekov, Shakhnazarova and Shirinya 1997: 191). In the situation when many conspicuous workers of the Comintern became victims of repression, the activity of the governing bodies of the ECCI decreased. This can be illustrated by the fact that between two meetings of the ECCI in 1938 (on August 16 and December 26, respectively) there was an interval of four and a half months (Adibekov, Shakhnazarova and Shirinya 1997: 193).

The repressions started with the arrests of the leaders of the Communist Party of Poland, including Julian Leszczyński, the secretary-general of the Communist Party, and others. In general, the NKVD preferred those members of foreign Communist Parties who were driven underground, so in their case there could hardly be any 'diplomatic complications' (Buber-Neumann 1995: 250; Conquest 2009: 672). The arrested heads of the Polish section of the CPP began to give testimony concerning the leadership of the ECCI. Among the first arrested was Melnikov, who conducted all assistant activities in preparing employees for the Comintern various tasks abroad, including the provision of documents, special means, organization of radio communication, and encryption cases. He led the Department of International Relations (DIR), and then the Communications Service (CS) of the Comintern, which would be 'most clogged' (Adibekov, Anderson and Shirinya 2004: 749). It was this service that sent couriers to the communist parties abroad, and organized contact points in various countries of the world. Subsequently, there were arrests of executives who were responsible for illegal channels of communication between the Comintern parties in different countries. As for Osip Piatnitsky, the head of administrative and political department of the Central Committee of the VKP(b) and Vilgelm Knorin, the deputy head of the Department of Propaganda and Agitation of the Central Committee of the $\operatorname{VKP}(\mathrm{b})$ who worked in the Comintern until 1935, and others, according to Khaustov and Samuelson, were accused of what they had planned: the disruption of the Comintern and a gradual seizure of the ECCI apparatus; the unification of Trotskyist and other 
opposition forces within the Communist Party in order to paralyze its work; organization of systematic illegal activities of the ECCI and its parties in capitalist countries; carrying out anti-Soviet propaganda; removing and discrediting certain Comintern leaders; struggle for leadership in certain Communist parties, the withdrawal of these parties from the Comintern and their joining the Fourth International (Khaustov and Samuelson 2010: 186). The NKVD investigators put forward the version about their contacts with Leon Trotsky's son Lev Sedov, which was carried out through Münzenberg, the member of the German Communist Party residing in Paris. There was thought to be a constant exchange of information about the state of the international communist movement and besides, Münzenberg received money from the ECCI. Another 'vicious' act was the organized resistance to the new leadership of the ECCI, namely, Dimitrov before and during the VII Congress of the Comintern. The speech of Harry Pollitt (General Secretary and Chairman of the Communist Party of Great Britain) in defense of Piatnitsky in the Presidium of the VII Congress was regarded by the Hungarian communist Béla Kun, the Assistant Chief of the $4^{\text {th }}$ Red Army Management Staff Alexander Abramov-Mirov and Richard Mering as a schismatic action. The external factors contributing to increasing repressions against the leaders of the Comintern were the defeat of the communists in parliamentary elections in Germany and the rise of the National Socialists led by Adolf Hitler.

In this respect, the case against Willi Münzenberg, the representative of the Communist Party of Germany (Kommunistische Partei Deutschlands, KPD) and one of its founders, as well as other creators of the anti-fascist policy is quite indicative in the context of elimination of political opponents during the described period. Münzenberg, an active anti-militarist, a member of the Spartakusbund, joined the socialist party early enough to leave after meeting Lenin in Zurich. Soon, in 1919 Lenin invited Münzenberg to Moscow. Shortly thereafter he was among the representatives of a network of various societies that were engaged in propaganda of the Soviet experience. The main social groups, which Münzenberg appealed to, were intellectuals, artists and cultural elite. As M. Sperber wrote about him,

he pushed writers, philosophers, artists of all kinds to certify their own signatures as belonging to the foremost ranks of the most radical fighters ... he thus had in place a whole set of intellectuals who only waited for his sign to hit the road with him; he chose the direction of motion himself (Sperber 2003: 92). 
The French historian studying communism, François Furet characterizes Münzenberg during the anti-fascist turn, as a person who became something like "the world underground minister of propaganda of the Comintern, whose influence was first of all perceived in Western Europe' (Furet 2007: 347). Münzenberg was accustomed to living in the periphery of the communist movement and would use his charisma and agitator skills to attract the attention of those who sympathizeв with communist movement. This caused certain suspicions in Moscow.

By 1936, Münzenberg remained a faithful follower and supporter of Stalin and Soviet foreign policy, despite his conflict with the German communist Walter Ulbricht on the further fate of the German Volksfront. The result of this conflict was a gradual departure of Münzenberg from the Comintern and his drift to the opposition to the Stalinist regime in 1936. In October 1936 Dimitrov offered Münzenberg to head the propaganda department. But the latter refused. Had he agreed to head the department, the 'Münzenberg problem' would most likely have been resolved within the framework of the Great Terror; however, he remained in Paris. Ulbricht, the member of the KPD in the exile, was aware of Münzenberg's possible fate, if the latter had appeared in Moscow which he later confessed to Otto Klepper, the German lawyer and former Prussian minister of finance (Braskén 2011: 12). Another confirmation we find in Dimitrov's diary entry on November 11, 1937, that is the record of his conversation with Joseph Stalin, who calls Münzenberg a 'trotskyist' and suggests trying to lure him to Moscow to arrest (Dimitrov 2003: 69). On March 21, 1938, Wilhelm Pieck, with the consent of the Kremlin, sends to Dimitrov a draft resolution to exclude Münzenberg from the Central Committee of the KPD (Courtois 1994: 35). In 1939, he decides to leave the KPD, finally breaking with Stalin's communism.

The beginning of mass repressions in the Comintern is connected with the arrests of former leaders of the International Relations Department Boris Melnikov and Alexander Abramov-Mirov. In April 1937, after the acquaintance with the materials of Madyar's interrogation, Joseph Stalin instructed Yezhov to arrest Melnikov and his 'environment'. At the end of May, Stalin receives Melnikov's confession where he points to Abramov-Mirov as an accomplice in the 'counterrevolutionary organization'. With Stalin's sanction and on Yezhov's proposal, Abramov-Mirov was arrested.

According to Khaustov and Samuelson's research, the testimonies of Melnikov and Abramov-Mirov led to the arrest of the leaders of the 
contact points in Warsaw, Paris, Stockholm and Copenhagen. By early July 1937, more than 20 activists had been arrested. They were arrested by Knorin and Piatnitsky. Bela Kun was arrested after Stalin's personal instructions. According to the NKVD investigators, 'the counterrevolutionary Trotsky-right organization' was formed in the ECCI with a number of leaders of the Comintern playing there a major role. Piatnitsky was appointed its leader (Khaustov and Samuelson 2010: 188). Meanwhile, new data, especially the information from the famous Russian historian F. Firsov, testifies that a full-scale destruction of the Comintern and of the entire political emigration in the USSR was planned in the immediate physical sense the fourth major show trial against the Comintern was to become the signal for the action (Firsow 1993; Starkov 1994).

Other representatives of Communist parties in the Comintern who lived at the 'Lux' Hotel also failed to escape the arrests. According to Buber-Neumann, already after the first trial some of those who lived at the 'Lux' Hotel found themselves an 'important job': 'they became agents of the State Political Directorate (GPU) and informed their compatriots' (Buber-Neumann 1995: 249). Suspicion was spread among the apparatus of the Comintern and spyware was spread to Soviet society. Among the arrested communist leaders there were Heinz Neumann, Hermann Remmele, Fritz Schulte, Hermann Schubert, Leo Flieg, Heinrich Süßkind and Hugo Eberlein, all former members of the Politburo of the KPD. In addition to Bela Kun, all the People's Commissars (12 people) of the ephemeral communist government in Budapest were arrested and executed. About 200 Italian and 100 Yugoslav Communists were arrested as well (Courtois et al. 2001: 198).

The terms separating the expulsion from the party and arrest varied: as noted by the authors of the Black Book of Communism, O. Walter was expelled from the Secretariat of Dimitrov on October 16, 1938. She was arrested two days later. Jan Borovsky (Ludwik Komorowski) was expelled from the ECCI on July 17 and was arrested only on October 17, 1937. Some were arrested directly at their workplaces, like A. Krajewski, responsible for the press and propaganda service. Many were arrested after their return from foreign missions. Moskvin was arrested on November 23, 1938 and executed on February 1, 1940, Anvelt died of torture. Fifty officials, including nine women, were shot (Courtois et al. 2001: 284). According to Panteleïev, these purges had the specific purpose of eradicating any opposition to the Stalinist dictatorship (Panteleïev 1994/1995: 48). 
As for the Communist Party of Poland (CPP), it was unofficially liquidated on November 28, 1937. Actually, the decision of the Presidium of the Executive Committee of the Communist International (ECCI) and the Resolution of the Secretariat of the ECCI was held and officially approved by the Presidium of the ECCI only on August 16, 1938, Record No. 27 (B) and 337 (B) respectively (RGASPI 505/1/74). These documents were adopted post factum, when the leaders and the head of the Central Committee of the CPP were liquidated. This event was preceded by a gradual elimination of the ruling elite of the Central Committee of the CPP so the party could hardly function in a proper way. By the series of resolutions and punitive operations the NKVD by Stalin's consent subjected to repression not only the Polish Communists, but also the Polish representatives and political immigrants living in the USSR.

According to the Russian historian V. Roginsky, the reasons for a complete elimination of the PCP root back to the first half of the 1920 s, when its leadership supported the left opposition in the RKP(b) (Roginsky 1997). Since that time Stalin felt certain distrust to the Poles. The first repressions of the Polish Communists began in the late 1920 s, when the party split into the 'right' and 'left' factions. The state of CPP in the late 1920s caused anxiety among the leaders of the VKP(b) and of the Comintern since the latter considered Poland as an important ally in the new imperialist war, and regarded the CPP as an extremely important party. In order to overcome the factional split, in August 1928, Vyacheslav Molotov who was engaged in the most important Comintern affairs at Stalin's request suggested his own plan for resolving the factional struggle in the CPP and the formation of a new Central Committee (Adibekov, Anderson and Shirinya 2004: 543-545). The measures proposed by Molotov ultimately led to the transition of power to the 'left'. The intervention of the Comintern and Stalin in the affairs of the Polish Communist Party took place, but not as radical as we can read in the 1929 'Bulletins of the oppositionist', which states that 'the Comintern, with the help of the GPU,' ruled 'the dispute between the "right" groupings of the Central Committee of the Polish Communist Party (A. Warski, M. Koszutska (W. Kostrzewa), etc.) and "left" (group of Leszczynski "Lenski"), sending the majority to the right of exile' (Bulletin of the opposition No. 66-67 (May - June 1938)).

At the same time the repressions against the activists of the Communist Parties of Western Ukraine and Western Belarus were initiated. After announcing that Józef Pilsudski's agents belong to the Polish 'rights', numerous arrests took place in 1933. In 1933-1934, 
several members of the Central Committee of the Communist Party and communist deputies of the Polish Sejm were shot. After that, Lenski's group declared the 'destruction of provocateurs' and 'purification of the atmosphere' in the CPP. After this, the Kremlin only defined the policy of the Polish Communists, who initially took the position of ultra-right but later dramatically changed it to the tactics of the 'people's front'.

A new stage of repression, this time against the ethnic minorities in the USSR, including the Polish minority living in the border areas of the Belorussian and Ukrainian SSRs, begins in the mid-1930s, almost immediately after the 'tampering' of the checkpoint. This was due to the fact that the rise of fascist and authoritarian regimes in Germany and Central and Eastern Europe, including Poland (Pilsudski's regime), as well as the convergence on the international scene of Germany with Poland, forced the Soviet Union to change the functioning regime in the border areas. From now on, the official Soviet propaganda would use the phrase from the letter from Kaganovich to Stalin (August 11, 1932) (Davies, Khlevniuk and Rees 2001: 274) emphasizing the transformation not only of the Ukrainian SSR, but of the whole Soviet Union into a 'vanguard' in the face of foreign influences. According to the American historian Martin, the repressions on the basis of nationality were explained by the fact that the border ethnic minorities, including the Poles, 'had transboundary ethnic ties with another national state' (Martin 2013: 426-427). The possible pretext was the German campaign in 1933-1934 to help German 'brothers in trouble' - the victims of famine in the USSR. This campaign demonstrated the ability of foreign governments to use national minorities as weapons against the Soviet Union. Later, the Poles addressed the Polish consul in Kiev with the same request. This, along with the concern of the head of the Belarusian government, Nikolay Goloded about the situation in the border areas, where 'the possibility is not excluded $\langle\ldots\rangle$ of the preparation by the Polish fascism of this territory for the future' was a good reason for the start of ethnic cleansing and a gradual elimination of Polish national institutions that were then considered 'unreliable'. A remarkable fact here is that the ethnic purge involved not only border areas, but it also spread inside the country, covering the whole territory of the USSR. The repressions against ethnic Poles who held various positions in the party and Soviet apparatus, the NKVD and the Red Army bodies began at the end of 1936 - early 1937 (Courtois et al. 2001: 186). In 1936, the Party Control Commission and the NKVD began purging among political emigrants, focusing 
on the Poles. According to the Russian historian Khaustov (1997), this purge quickly transformed into a campaign of mass arrests. With the launch of 'massive operations' of the Great Terror in the summer of 1937, the terror against the elite - the foreign communists - merged with ethnic terror that was directed against its own citizens of diaspora nationalities, which resulted in a mass campaign of terror against a new category of hostile nationalities. Some of the arrests of the PCP representatives were the result of a campaign to eliminate the longexisting Polish Military Organization (PMO). This can be proved by the fact that on August 11, 1937 the Politburo approved the operative order of the People’s Commissar of Internal Affairs № 00485 on repression against the members of the Polish Military Organization (PMO), prisoners of war of the Polish army, defectors from Poland, political emigrants and political exchanges from Poland, and former members of Polish political parties (Yakovlev 2004: 301-303). On August 13, Yezhov signed the order and defined who should be arrested - all political immigrants and fugitives, 'the most active part of the local nationalist elements of the Polish national areas' (Shapoval, Prystaiko and Zolotariov 1997: 348). In October 1937 this category was expanded to include all Poles with 'consular ties' (almost all Poles in the USSR) (Petrov and Roginsky 1997). In 1938, the NKVD arrested the Poles, as well as the representatives of other nationalities, basing mostly on ethnicity (Bilokin 1993: 40-41). The Politburo Resolution of 15 January 1938 was prolonged until April 15, 1938 'the operation to defeat espionage and sabotage troops among Poles, Latvians, Germans, Estonians, Finns, Greeks, Iranians, Harbinese Chinese and Romanians as foreign nations and Soviet citizens, in accordance with the existing orders of the NKVD of the USSR'. People were arrested on the 'Polish line' or the 'German line' of national terror (Petrov and Roginsky 1997). The number of executed prisoners and minorities, unfortunately, is not known for sure, since not everyone arrested during the Polish operation was a Pole, as not all Poles were arrested for 'Polish Line'. All national institutions on the USSR territory were declared 'artificially created', in other words - historically unjustified. Moreover, as Martin noted basing on the processed documents, one of the delegates at the October plenum (1937) said: 'The Poles, working through their own agents, national fascists and trotskyist spies strengthened the border areas with their own people' (Martin 2013: 441). Thus, the party formulated a publicly undisclosed explanation of national terror as part of the Great Terror. Petrov and Roginsky estimated that 139,835 people were arrested as a result of 
the 'Polish operation', while the total number of all Poles arrested in all national operations conducted under № 00447 order counted $118,000-123,000$ people for the whole period of the Great Terror (Petrov and Roginsky 1997).

In 1937 almost all Polish Communists, who stayed in the USSR, were arrested. Some of them occupied positions in the structures and divisions of the Third International, which created the necessity to exclude and condemn them. The document of the session of the International Control Commission (ICC) of November 22, 1937, is rather characteristic in this respect. The Polish Communists, who were part of the ICC (Franciszek Grzegorzewski, A. Krajewski and G. Wałecki) were expelled from their own Communist parties as enemies of the people and arrested by the Soviet authorities. The session of the ICC decided to exclude the Polish comrades, arrested by the Soviet authorities and expelled from the CPP as nation's enemies. This logic is quite simple - you are branded as 'nation's enemy' then excluded from the party and the NKVD takes you. The evidence would appear as soon as they needed it. The sentence followed the investigation. A pure precession of simulacrum. According to American historian Chase, this document 'symbolizes the fate of many Poles who lived on the territory of the USSR' (Chase 2001: 286). In February 1938, the Comintern official newspaper 'La Correspondance Internationale' issued twice a week, published the accusation for the entire CPP, signed by J. Svisiski. During the period of 'purge', which began in June 1937, twelve leading members of the Communist party of Poland, who stayed in the USSR, were killed or disappeared (including General secretary Lenski and 70-year-old Adolf Warski, one of the founders of the Polish Social-Democratic and Communist party, as well as other Polish representatives, who occupied positions in the top authorities of the Third International). The Poles participating in international brigades (political leaders of the brigade of Dombrovsky, K. Chikhovski and G. Reicher) were detained immediately after returning from Spain to Moscow (Courtois et al. 2001: 289).

The analysis of documents on the dissolution of the Communist Party of Poland, the establishment of the initiative group, which had to be temporarily engaged in Polish affairs and the letter from Dimitrov to Stalin on November 28, 1937 clarified the logic and the role of Stalin in these events.

The resolution of the ECCI can be clearly divided into several parts. The first part, or preamble, denouncing Polish fascism that made 'espionage, sabotage and provocation an important weapon in 
their struggle against the labor movement, against all anti-fascist, democratic forces poisoned by this shameful system of all political and social life of Poland' defines its main purpose 'to infiltrate the communist movement, which represents the greatest threat to Polish fascism'. By combining the members of anti-fascist and democratic forces into one unit and opposing them to fascism, the preamble, thus forms an image of an abstract enemy hiding behind the vague definition of 'Polish fascism.'

The second part of the document, or accusations, begins with the fact that the 'Presidium of the Executive Committee of the Communist International on the basis of incontrovertible documentary data', which the Bureau of the ECCI actually did not define, revealed that for several years 'enemies, the agents of Polish fascism' worked in the CPP and they had been sent to the CPP under the guise of 'opposition elements, and then penetrated into the communist movement', and 'promoted their agents to the leadership positions in the Communist Party'. At the same time, 'Polish fascism widely used the TrotskystBukharin freaks' and 'stirred up the fractional struggle in the party'. The accusation ends with the fact that 'all attempts to expel the agents of Polish fascism $<\ldots>$ while maintaining the present organization [...] failed'. The document on the dissolution of the CPP is an example of one of many operations for the real dissuasion that was conducted throughout the whole period of the Great Terror and after it.

Since the CPP turned out to be an 'incurable patient', the Presidium of the ECCI was left with no choice but to dissolve the CPP with recommendations to 'all honest Communists to shift the main focus of their work on mass organizations, which are working and fighting for the unity of the anti-fascist forces and movements of the national front in Poland' (RGASPI 505/1/74). As Chase pointed (2001: 286), the decision to dissolve the CPP, approved by the ECCI on November 28, 1937, was adopted five days earlier, on November 23, by Dimitrov, Manuilsky, Kuusinen, Moskvin, and Pieck. On November 28, Dimitrov sent a letter to Stalin with the text of resolution. In the letter Dimitrov also asked for advice and guidance concerning the following issues: was it necessary to make a statement on the dissolution of the CPP while the investigation was underway or it was necessary to wait; and, what character should have a decree on the dissolution of the CPP (Adibekov, Anderson and Shirinya 2004: 758). Stalin made an indicative note on Dimitrov's letter: 'The dissolution is two years late. It should be dissolved, but should not be published in the press, in my opinion' (Adibekov, Anderson and Shirinya 2004: 760). 


\section{CONCLUDING REMARKS}

By creating a non-referential field, where the relationship between a sign and real-world objects was blurred or absent and there was used precession and dissuasion of the reality, there was created a system with reality necessary for the party and created and distributed by it. In other words, the expanded terror during the period of 1936-1938 helped to form a required space for the then existing regime and for the necessary repressive measures (according to Joseph Stalin and his surroundings) that would strengthen solidarity and defense of the USSR before the start of the new world war. Strengthened by constant suspicions, the repression against political opponents of the $\operatorname{VKP}(b)$ transformed into a total terror against the country's population and ethnic minorities living in border regions, particularly against the Polish minority. Covering all the structures the terror could not but spread to the Third International, whose representatives, due to their foreign origin and family ties with nation-states turned the preferred victims of repression. Purge and repression overtook the entire apparatus of the Comintern, causing much harm to communication services, which was completely rebuilt and reorganized and the secretariats of the ECCI. One sixth of the apparatus of the Comintern was subjected to 'purge'. However, the indicative process that was prepared, as the Russian historian Firsov suggests, against the Third International, did not take place. The further research and discovery of new documents concerning repression of the Comintern, could clarify Prof. Firsov's assumptions.

Speaking about national sections, the Communist Party of Poland, which was secretly liquidated in November 1937, suffered the most, and all members of the Central Committee and Poles-functionaries of the Comintern and its subdivisions were repressed. The liquidation of the CPP became officially known only a few months later, in August 1938. The elimination of the CPP and repressions against the Poles in the USSR took more than 100,000 lives.

\section{REFERENCES}

Adibekov, G., Anderson, K., Shirinya, K. (eds.). 2004. Politburo of the Central Committee of the RKP $(b)-V K P(b)$ and the Comintern: 1919-1943. Documents. Moscow: ROSSPEN. Original in Russian (Адибеков, Г., Андерсон, К., Шириня, К. (ред.) Политбюро ЦК РКП(б) - ВКП(б) и Коминтерн: 1919 1943 ге. Документы. М.: РОССПЭН).

Adibekov, G., Shakhnazarova, E., and Shirinya, K. 1997. The Organizational Structure of the Comintern. 1919-1943. Moscow: ROSSPEN. Original in Russian 
(Адибеков, Г. М., Шахназарова, Э. Н., Шириня, К. К. Организационная структура Коминтерна. 1919-1943. М.: РОССПЭН).

Babičenko, L. 1994/1995. Die Moskvin-Komission. Neue Einyelheiten zur politisch-organisatorischen Struktur der Komintern in der Repressionsphase. The International Newsletter of the Historical Studies on Comintern, Communism and Stalinism 5/6: 35-40. Berlin: Akademie Verlag.

Baudrillard, J. 2015. Simulacrum and Simulation. Moscow: POSTUM. Original in Russian (Бодрийяр, Ж. Симулякры и симулящии. М.: ПОСТУМ).

Bilokin, S. 1993. Documents on the History of the NKVD of the USSR: Publication of 45 Documents. Our Past: Journal of Independent Historical Thought. Ch. 1 (6): 39-150. Kyiv: M. Kotz Publishing House. Original in Ukrainian (Білоконь С. Документи з історії НКВД УРСР: Публікація 45 документів. Наме минуле: Журнал незалежної історичної думки. Ч. 1 (6). К.: Видавництво М. Коця).

Braskén, K. 2011. 'Hauptgefahr jetzt nicht Trotzkismus, sondern Münzenberg' East German Uses of Remembrance and the Contentious Case of Willi Münzenberg. CoWoPa-Comintern Working Papers 22: 1-30. URL: https://www. abo.fi/student/media/7957/cowopa22bras ken.pdf.

Buber-Neumann, M. 1995. The World Revolution and the Stalinist Regime: Notes of an Eyewitness about the Activity of the Comintern in the 1920-1930s. Moscow: AIRO-XX. Original in Russian (Бубер-Нейман, М. Мировая революция и сталинский режим: записки очевидия о деятельности Коминтерна в 1920-1930-х годах. М.: АИРО-ХХ).

Bulletin of the Opposition No. 66-67 (May - June 1938). Original in Russian (Бюллетень оппозиции № 66-67 [май - июнь 1938 г.]). URL: https://web. mit.edu/fjk/FI/BO/BO-66.shtml.

Chase, W. 2001. Enemies within the Gates? The Comintern and the Stalinist Repression, 1934-1939. Yale: Yale University Press.

Conquest, R. 2009. The Great Terror: Stalin's Purge of the Thirties. Lutsk: Teren. Original in Ukrainian (Конквест, Р. Великий терор. Сталінські чистки тридиятих років. Луцьк: Терен).

Courtois, S. 1994. La seconde mort de Willi Munzenberg. Communisme. 38/39: 25-41. URL: https://books.google.com.ua/books?id=kNY7Qlpt4zAC\&pg= $\mathrm{PA} 187 \& \mathrm{dq}=$ communisme + revue $+1994+38 \& \mathrm{hl}=$ ru\&sa $=\mathrm{X} \&$ redir $\mathrm{esc}=\mathrm{y} \# \mathrm{v}=$ on epage $\& \mathrm{q} \& \mathrm{f}=$ false.

Courtois, S., Werth, N., Panne, J.-L., Paczkowski, A., Bartosek, K., Margolin, G. L. 2001. The Black Book of Communism. Crimes, Terror, Repressions. Moscow: “Tri veka istorii". Original in Russian (Куртуа, С., Верт, Н., Панне, Ж.-Л., Пачковский, А., Бартошек, К., Марголен, Ж.-Л. Черная книга коммунизма. Преступления, террор, репрессии. М.: Три века истории).

Davies, R. W., Khlevniuk, O. V., Rees, E. A. (eds.) 2001. The Stalin-Kaganovich Correspondence. 1931-1936. Moscow: ROSSPEN. Original in Russian (Дэвис, Р. В., Хлевнюк, О. В., Рис, Е. А. (ред.) Сталин и Каганович. Переписка. 1931-1936 г2. М.: РОССПЭН).

Dimitrov, G. 2003. The Diary. 1933-1949. Yale: Yale University Press.

Firsow, F. 1993. Die Säueberungen im Apparat der Komintern. Kommunisten verfolgen Kommunisten. Stalinistischer Terror und 'Säueberungen' in der 
kommunistischen Parteien Europas seit den dreißiger Jahren. 37-51. Berlin: Akademie Verlag.

Furet, F. 2007. The Passing of an Illusion: The Idea of Communism in the Twentieth Century. Kyiv: DUHK I LITERA. Original in Ukrainian (Фюре, Ф. Минуле однієї ілюзії: Нарис про комуністичну ідею у XX столітті. К.: ДУХ І ЛІТЕРА).

Kaganovich, L. 1933. About Purge the Party. Moscow, Leningrad: Partizdat Original in Russian (Каганович, Л. М. О чистке партии. М., Л.: Партиздат). URL: https://stalinism.ru/dokymentyi/o-chistke-partii-postanovlenie-tsk-i-tskkvkpb.html.

Khaustov, V. 1997. From the Prehistory of Mass Repression against the Poles. The Mid-1930s. Historical Collections 'Memorial', 'Repression against Poles and Polish Citizens'. Original in Russian (Хаустов, В. Из предыстории массовых репрессий против поляков. Середина 1930-х годов. Исторические сборники «Мемориал», «Репрессии против поляков и польских граждан»). URL: http://old.memo.ru/history/POLAcy/ Index.htm.

Khaustov, V., and Samuelson, L. 2010. Stalin, NKVD and Repressions 19361938. Moscow: ROSSPEN. Original in Russian (Хаустов, В., Самуэльсон, Л. Сталин, НКВД и репрессии 1936-1938 г2. М.: РОССПЭН).

Martin, T. 2013. The Affirmative Action Empire. Nations and Nationalism in the Soviet Union, 1923-1939. Kyiv: Krytyka. Original in Ukrainian (Мартин, T. Імперія національного вирівнювання: начії та націоналізм в Радянському Союзі, 1923-1939. Киев: Критика).

Medushevsky, A. 2010. Stalinism as a Model of Social Construction. Russian History 6: 3-29. Original in Russian (Медушевский, А. Н. Сталинизм как модель социального конструирования. Российская история 6: 3-29). URL: http://www.rosspen.su/files/ru/news/Medushevskii.pdf.

Naimark, N. 2011. Stalin's Genocides. Kyiv: Publishing House 'Kyiv-Mohyla Academy'. Original in Ukrainian (Наймарк, Н. Геноциди Сталіна. Киев: Видавничий дім «Києво-Могилянська академія»).

Ochotin, N., Roginski, A. 2000/2001. Zur Geschichte der 'Deutschen Operation' des NKWD 1937-1938. Jahrbuch für Historische Kommunismusforchung: 89-125. Berlin: Akademie Verlag.

Panteleïev, M. 1994/1995. La Terreur stalinienne am Komintern en 1937-1938 Les chiffres et les causes. Communisme 40 (41): 37-53. Paris.

Petrov, N., and Roginsky, A. 1997. Polish Operation of the NKVD in 1937-1938. Historical Collections 'Memorial', 'Repression against Poles and Polish Citizens'. Original in Russian (Петров, Н. В., Рогинский, А. Б. Польская операция НКВД 1937-1938 гг. Исторические сборники «Мемориал», «Репрессии против поляков и польских граждан»). URL: http://old.memo.ru/ history/POLAcy/Index.htm.

RGASPI 505/1/74. Original in Russian (РГАСПИ Ф. 505. Оп. 1. Д. 74).

RGASPI 546/1/418. Original in Russian (РГАСПИ Ф. 546. Оп. 1. Д. 418).

Roginsky, V. 1997. Party of the Executed. Moscow: Moscow Printing House No. 3 RAN. Original in Russian (Рогинский, В. 3. Партия расстрелянных. M.: Московская типография № 3 PAH). URL: https:// stuff.mit.edu/people/ fjk/Rogovin/volume5/index.hrml. 
Shapoval, Y., Prystaiko, V., Zolotariov, V. 1997. Cheka-GPU-NKBD in Ukraine: Persons, Facts, Documents. Kyiv: Abrys. Original in Ukrainian (Шаповал, Ю., Пристайко, В., Золотарьов, В. ЧК-ГПУ-НКВД в Украӥні: особи, факти, документи. К.: Абрис).

Sperber, M. 2003. Les visages de l'hisroire. Paris: Editions Odile Jacob. URL: https://books.google.nl/books?id=_XKjyjlt-2YC\&pg=PA85\&dq=Manès+Sper ber+Munzenberg\&hl=ru\&sa $=X \&$ redir_esc $=\mathrm{y} \# \mathrm{v}=$ onepage $\& \mathrm{q}=\mathrm{Man} \% \mathrm{C} 3 \% \mathrm{~A} 8 \mathrm{~s} \%$ 20Sperber\%20Munzenberg\& $\mathrm{f}=$ false.

Starkov, B. 1994. The Trial that was not Held. Europe-Asia Studies 46: 12971315. Abingdon: Taylor \& Francis, Ltd.

Studer, B., and Unfried, B. 2011. Stalin's Party Cadres. The Practice of Identification and Discourses in the Soviet Union of the 1930s. Moscow: ROSSPEN. Original in Russian (Штудер, Б., Унфрид, Б. Сталинские партийные кадры. Практика идентификации и дискурсы в Советском Союзе 1930-х г2. М.: РОССПЭН).

Vatlin, A. 1998. Kaderpolitik und Säuberungen in der Komintern. Terror. Stalinistische Partieisäuberungen 1936-1953: 33-119. Paderborn: Schöningh.

Werth, N. 2010. Terror and disorder. Stalinism as a system. Moscow: ROSSPEN. Original in Russian (Верт, Н. Террор и беспорядок. Сталинизм как система. М.: РОССПЭН).

Yakovlev, A. (ed.) 2004. Lubyanka. Stalin and the Main Department of State Security of the NKVD. Archive of Stalin. Documents of the highest organs of party and state power. 1937-1938. Moscow. MFD. Original in Russian (Яковлев А. (ред.) Лубянка. Сталин и Главное управление госбезопасности НКВД. Архив Сталина. Документы высших органов партийной и государственной власти. 1937-1938. М.: МФД). 